\title{
DIGITAL LITERACY ANALYSIS OF CHEMISTRY EDUCATION STUDENTS IN USING THE CHEMDRAW APPLICATION
}

\author{
Ella Izzatin Nada* and Wiwik Kartika Sari
}

Department of Chemistry Education, Faculty of Science and Technology, UIN Walisongo Jl. Walisongo No.3-5, Ngaliyan, Semarang City, Central Java 50185, Indonesia

*Correspondence: telp/fax : 082190117258, email: ellaizzatinnada@walisongo.ac.id

\begin{abstract}
Students digital competence abilities can be measured using the individual competence framework. There are five indicators used: information, communication, content creation, safety, and problem-solving. This study analyses students digital literacy profile with high, medium, and low ChemDraw skills. This research is a qualitative descriptive study. The trial was conducted on 25 Chemistry Education Students at UIN Walisongo Semarang with high, medium and low ChemDraw skills. Data were obtained using ChemDraw test instruments, observation and questionnaires. The data obtained were analysed based on digital literacy indicators to obtain student digital literacy profiles. The results showed that the digital literacy level of students with high ChemDraw skills had a moderate level of digital competence. Students with medium ChemDraw skills have a moderate level of digital competence. Meanwhile, students with low ChemDraw skills have a low level of digital competence.
\end{abstract}

Keywords: digital literacy. students, ChemDraw

\section{INTRODUCTION}

The technology field's transformation currently penetrates the 4.0 industrial revolution, where technology has become the basis and is directly connected in human life [1]. Everyone is free to enter information in cyberspace without restrictions. This change occurs so rapidly that it has changed the way of life, work, economy, and relationships without us knowing it, including how to do activities in people's daily lives [2]. Willems, Farley, \& Campbell argue that every individual in society can participate in the current digital era [3]. Hakim argues that the development of information technology and the internet has consequences for producing and distributing information easily and quickly [4].

Digital literacy has become an urgent need for today's society. According to Koltay, digital literacy leads to information and communication technology (ICT) to use digital media by teachers in learning [5]. Digital literacy is not just the ability to find, use and disseminate information. It requires the ability to make information and critical evaluation, the accuracy of the application used and a deep understanding of digital content information.

Digital literacy has an essential role in teachers' education to adapt to digital trends and students' needs in the classroom [6]. 
Zhang revealed that digital literacy is a skill required to become a society in facing the 21 st century, including understanding the characteristics and features of digital techno-logy and digital effects [7]. Teachers have to learn to select, create, modify, manage, protect and share their digital resources [8].

As prospective educators in the future with the increasing development of digital technology, Chemistry education students are expected to master digital literacy well and apply it to implement learning activities to achieve the educational goals. The majority of young people who come to the university do not have the skills needed to use the Internet and information technology to solve scientific problems, perform different tasks individually or in a team. They are good at using social networking, e-mails or skype and surfing the internet. Still, their knowledge and competences for effective use of new technology in the learning process are often superficial [9].

Students who generally interact with technology do not necessarily have a good understanding of digital literacy [10]. Research on digital literacy that has been conducted by Mery Yanti gives the result that the importance of an ICT competency assessment instrument for students is to find out how high the ICT competence a student has [11]. This implies that analysing students' digital literacy understanding is an important thing to do. Kurniawati \& Baroroh argue that digital media literacy of Muhammadiyah Bengkulu students was at a moderate level, but their competence was at a primary or low level. This study also reveals that someone who always uses gadgets or digital does not necessarily know digital literacy [6].

Highlights the wide range of emerging technologies used in teaching and learning, supporting understanding and creating, supporting learning through collaboration, enabling anytime, and anyplace learning. Emerging technologies present another challenge to assuring that teacher educators are indeed competent [12]. In the digital era, teachers are expected to become technologically oriented, be more collaborators, openminded, critical, professionals and facilitators who will help students analyse the quality of new sources and learn in a digital environment. Those skills are meaningful for every modern teacher who wants to develop digital literacy and include new pedagogical practice technologies [8].

Studies of digital literacy accentuate the need of getting beyond the necessary skills of using the information, digital literacy tools and resources, developing strategies for critical and efficient use of these means contain increasing levels of cognitive competence in utilising the literacy in question for tasks, learning, creating and expressing new ideas [9].

Researchers used participatory observation, and it is necessary to analyse students' understanding of digital literacy and its application in using the ChemDraw application. In addition, to find out the readiness of students to compete in the era of the industrial revolution 4.0.

\section{METHODS}

The research method used is descriptive qualitative [13]. This research was conducted in the chemistry education 
department of UIN Walisongo Semarang. The subjects in this study were 25 chemistry education students class of 2017 who took computational chemistry courses. Data collection techniques in this study were: (1) ChemDraw ability test, (2) observation, and (3) digital literacy questionnaire. This study analyses respondents 'digital literacy skills and observes the respondents' ability to use technology, filter information, evaluate information obtained, and solve problems. This research also analysed how respondents used their digital literacy skills to operate the ChemDraw application. Indicators used in measuring digital literacy [14] presented in Table 1.

Table 1. Digital Literacy Indicators

\begin{tabular}{|c|c|c|}
\hline No & Dimension & Indicator \\
\hline 1 & Information & $\begin{array}{l}\text { 1.1 explore chemical information through digital technology } \\
1.2 \text { identify chemical information encountered through digital } \\
\text { technology } \\
1.3 \text { evaluating chemical information obtained through digital } \\
\text { technology } \\
1.4 \text { stores chemical information retrieved via digital devices }\end{array}$ \\
\hline 2 & Communication & $\begin{array}{l}2.1 \text { discuss chemical materials via digital devices } \\
2.2 \text { share chemicals via digital devices } \\
2.3 \text { active discuss online in the groups to expand the network } \\
2.4 \text { collaborate in the digital building of chemical resources and } \\
\text { content }\end{array}$ \\
\hline 3 & Content-creation & $\begin{array}{l}3.1 \text { create and develop chemical content } \\
3.2 \text { understand the copyright and license of a digital work } \\
3.3 \text { modifying software and applications }\end{array}$ \\
\hline 4 & Safety & $\begin{array}{l}4.1 \text { the ability to protect personal data } \\
4.2 \text { the ability to protect personal health from the dangers of the } \\
\text { digital world } \\
4.3 \text { the ability to protect owned digital devices } \\
4.4 \text { the ability to protect the environment from the digital world }\end{array}$ \\
\hline 5 & Problem Solving & $\begin{array}{l}5.1 \text { the ability to solve technical problems } \\
5.2 \text { the ability to innovate in chemistry with digital technology } \\
5.3 \text { identify the needs and responses of technology in chemistry } \\
\text { learning } \\
5.4 \text { identifying digital competency gaps }\end{array}$ \\
\hline
\end{tabular}

\section{RESULT AND DISCUSSION}

In the study results, the researcher described the data obtained during the study regarding students' digital literacy level to use ChemDraw. After getting the data on the ability to use ChemDraw, the data analysis process was carried out on the students' digital literacy skills.

The results of the ability to use ChemDraw can be seen from the test results. The test results then categorised into the high, medium and low ability. The test results are presented in Table 2.

Tabel 2. ChemDraw Test Result

\begin{tabular}{ccc}
\hline No & Category & Number of Students \\
\hline 1 & High & 8 \\
2 & Middle & 10 \\
3 & Low & 7 \\
\hline
\end{tabular}


The analysis results of these indicators are then described in detail based on the level of ability to use ChemDraw as follows:

\section{Analysis of students digital literacy with a high level of ability to use Chem- Draw}

That results of students' digital literacy analysis with a high level of ability to use ChemDraw can be seen in Table 3.

Table 3. Analysis of digital literacy of students with a high level of ability to use ChemDraw

\begin{tabular}{cll}
\hline No & \multicolumn{1}{c}{$\begin{array}{c}\text { Indicator of Digital } \\
\text { Literacy }\end{array}$} & Category \\
\hline 1 & Information & High \\
2 & Communication & High \\
3 & Content-creation & Medium \\
4 & Safety & Medium \\
5 & Problem Solving & Medium \\
\hline
\end{tabular}

Based on the data above, it is explained that subjects with the high ability to use ChemDraw have a high level of information, this is because subjects with high ChemDraw skills can use and operate digital media actively. Subjects with high ChemDraw skills are categorised in high communication indicators. This is following the research conducted [15], who stated that communication skills are the ability to collaborate and interact, which allows them to participate in network communities.

Based on the media literacy competency level by the European Commission, students' abilities at the basic level, students already have a set of abilities that allow essential use of digital media. However, they still have limitations [16]. Subjects with high ChemDraw skills can understand analysing but not yet able to evaluate digital media use. Subjects with high ChemDraw ability were categorised in the medium content-creation indicator. This is consistent with the research conducted by Juliana Kurniawati, and Siti Baroroh stated that content-creation is a cognitive ability in using media such as the ability to understand, analyse, and evaluate media content [6]. Subjects with high ChemDraw skills are categorised in the medium of the problem-solving indicator. Person's ability to solve problems and build social relations through the media can also produce media content.

Based on the study results, it can be concluded that students with high levels of digital literacy have met one of the $21^{\text {st }}$ century skills and are ready to face the challenges of industry 4.0 [17]. Students with high category ChemDraw usage skills have mastered digital-based learning media that support students' digital literacy.

\section{Analysis of students digital literacy with a moderate level of ability to use ChemDraw}

The results of the students' digital literacy analysis with a moderate level of ability to use ChemDraw can be seen in Table 4 .

Table 4. Analysis of students digital literacy with a moderate level of ability to use ChemDraw

\begin{tabular}{cll}
\hline No & \multicolumn{1}{c}{$\begin{array}{c}\text { Indicator of Digital } \\
\text { Literacy }\end{array}$} & Category \\
\hline 1 & Information & High \\
2 & Communication & High \\
3 & Content-creation & Medium \\
4 & Safety & Low \\
5 & Problem Solving & Low \\
\hline
\end{tabular}

Based on the results of the study, it shows that ChemDraw's ability is having a relationship with students' digital literacy. 
However, it is not the only determining factor for students' high digital literacy but at least by studying and using the ChemDraw application accustomed students to using digital-based learning media. There are two main components to using ChemDraw skills: Technical Skills and Critical Understanding [16]. This study's technical skill category understands each toolbar's function in the ChemDraw application and knowing the content in the Chemdraw application, which is useful for working on chemical exercises. The critical understanding category focuses on students' cognitive abilities in using media, doing chemistry exercises using the ChemDraw application, identifying and analysing the answers obtained through the ChemDraw application, and evaluating the ability to use the ChemDraw application.

This study's results indicate that the ability to use ChemDraw affects the digital literacy level of students. Other study concluded that students' digital literacy skills could not be considered all the same, even though most students are digital literate generations [18]. Educators and students need to re-examine what digital literacy skills mean for them so that policymakers can determine what to do to improve the young generation's digital literacy. Respondent's digital literacy in this study depends on several factors. The difference in this study is the research subject used.

\section{Analysis of students digital literacy with a low level of ability to use ChemDraw}

The results of the digital literacy analysis of students with low ChemDraw usage skills in Table 5.
Table 5. Table Analysis of digital literacy of students with a low level of ability to use ChemDraw

\begin{tabular}{cll}
\hline No & \multicolumn{1}{c}{$\begin{array}{c}\text { Indicator of Digital } \\
\text { Literacy }\end{array}$} & Category \\
\hline 1 & Information & High \\
2 & Communication & Medium \\
3 & Content-creation & Medium \\
4 & Safety & Medium \\
5 & Problem Solving & Medium \\
\hline
\end{tabular}

The results showed that ChemDraw ability affected students' digital literacy. Low ChemDraw ability results in high aspects of digital literacy on information indicators only while others are low. Using ChemDraw familiarises students with knowing each toolbar's function in the ChemDraw application and knowing its content. This habit is essential for carrying out chemistry exercises to encourage students to seek information about this application, and this is Affordable Digital Literacy on Higher Information Indicators. Other indicators tend to be low because the ChemDraw application does not accustom students to adjusting chemical problems or communicating information and using passwords for security in the use of information technology to affect the results of students' digital literacy indicators. Based on the results of observations made by the researcher, subjects with low ChemDraw skills also tended to be less active in using and operating digital media.

Digital technology can play an essential and significant role in improving students' understanding of literacy, such as visual, digital, and critical literacy [15]. Digital technology is an important learning tool to help students interpret and communicate information in a multimodal manner. Digital 
technology effectively supports students' understanding and representation of chemical concepts at the macroscopic, molecular, and symbolic levels.

The results showed that there was a relationship between digital literacy and ChemDraw skills. On the basis that a person has digital literacy skills if he has various kinds of technical and cognitive skills in the use of digital media [19].

For further interpretation using the correlation interpretation table, the relationship between digital literacy and ChemDraw was included in the moderate correlation category. Digital literacy is not entirely a determinant of the high skills of using ChemDraw in students. Previous research states that digital literacy is not yet a determining factor in the skill level of using digital media [20].

Digital literacy is the awareness, attitude and ability of individuals to collect, access, manage, assess, integrate, evaluate, analyse using digital tools and facilities appropriately, build new knowledge, and communicate with others, thus enabling constructive social action. To master digital literacy requires individual competence consisting of technical competence, critical understanding, and communication and participation. Participants in this research were 25 students, eight students with high ChemDraw skills had medium digital competency levels, ten students with moderate ChemDraw skills had moderate digital competency levels, and seven students with low ChemDraw skills had low digital competency levels.

The digital literacy assessment results show that digital understanding literacy cannot be equated with students' exposure and interaction with digital technology in daily life. This indicates that although students have often interacted with digital technology, it does not mean that they have a good understanding of digital literacy, so it is necessary to develop a strategy to increase digital literacy for coherent, inclusive, and holistic students.

\section{CONCLUSION}

The digital literacy level of students with the ability to use ChemDraw is students with high ChemDraw skill have a medium level of digital competence, students with moderate ChemDraw skill have a medium level of digital competence, and students with low ChemDraw ability have a low level of digital competence.

\section{REFERENCES}

[1] M. Hermann, T. Pentek, B. Otto, and T. Pentek, "Design Principles for Industrie 4.0 Scenarios: A Literature Review Competence Center Corporate Data Quality (CC CDQ) View project Industrial Data Space View project Design Principles for Industrie 4.0 Scenarios: A Literature Review," 49th Hawaii Int. Conf. Syst. Sci., no. September 2016, p. 16, 2016. DOI: 10.1109/HICSS.2016.488

[2] W. Adiansah, E. Setiawan, W. N. Kodaruddin, and $\mathrm{H}$. Wibowo, "Person in Environment Remaja Pada Era Revolusi Industri 4.0," Focus J. Pekerj. Sos., vol. 2, no. 1, p. 47, 2019. DOI: 10.24198/focus.v2i1.23118.g11304

[3] J. Willems, H. Farley, and C. Campbell, "The increasing significance of digital equity in higher education: An introduction to the Digital equity special issue," Australas. J. Educ. Technol., vol. 35, no. 6, pp. 1-8, 2019.

DOI: $10.14742 /$ ajet.5996 
[4] H. A. B. Hakim, Aplikasi Teknologi Informasi Di Perpustakaan Sekolah: Dari Otomasi Sampai Literasi Informasi. Yogyakarta: Lembaga Ladang Kata., 2017. ISBN 9786026541178

[5] T. Koltay, "The media and the literacies: Media literacy, information literacy, digital literacy," Media, Cult. Soc., vol. 33, no. 2, pp. 211-221, 2011. DOI: $10.1177 / 0163443710393382$

[6] J. Kurniawati and S. Baroroh, "Literasi media digital mahasiswa Universitas Muhammadiyah Bengkulu," J. Komun., vol. 8, no. 2, pp. 51-66, 2016. Google Scholar

[7] H. Zhang and C. Zhu, "A Study of Digital Media Literacy of the 5th and 6th Grade Primary Students in Beijing," Asia-Pacific Educ. Res., vol. 25, no. 4, pp. 579-592, 2016.

DOI: $10.1007 / \mathrm{s} 40299-016-0285-2$

[8] M. Sharma, "Teacher in a Digital Era," Glob. J. Comput. Sci. Technol., vol. 17, no. 3, pp. 10-14, 2017.

Google Scholar

[9] T. Shopova, "Digital literacy of students and its improvement at the university," J. Effic. Responsib. Educ. Sci., vol. 7, no. 2, pp. 26-32, 2014. DOI: 10.7160/eriesj.2014.070201

[10] C. Murray and J. Perez, "Unraveling the Digital Literacy Paradox: How Higher Education Fails at the Fourth Literacy," Issues Informing Sci. Inf. Technol., vol. 11, pp. 85-100, 2014. Google Scholar

[11] M. Yanti, "Determinan literasi digital mahasiswa: kasus Universitas Sriwijaya [Determinants of students digital literacy: the case of Sriwijaya University]," Bul. Pos dan Telekomun., vol. 14, no. 2, pp. 79-94, 2016. DOI: 10.17933/bpostel.2016.140202

[12] A. C. Borthwick and R. Hansen, "Digital Literacy in Teacher Education: Are Teacher Educators Competent?," J. Digit. Learn. Teach. Educ., vol. 33, no. 2, pp. 46-48, 2017.

DOI: 10.1080/21532974.2017.1291249
[13] J. Creswell, Riset Pendidikan Perencanaan, Pelaksanaan, dan Evaluasi Riset Kualitatif dan Kuantitatif, Edisi Keli. Yogyakarta: Pustaka Pelajar, 2015. ISBN 978-602-229-474-0

[14] R. Rizal, W. Setiawan, and D. Rusdiana, "Digital literacy of preservice science teacher," J. Phys. Conf. Ser., vol. 1157, no. 2, pp. 1-6, 2019.

DOI: 10.1088/1742-6596/1157/2/022058

[15] A. Santoso, "Media Literacy Siswa Muslim Surabaya dalam Penggunaan Internet," J. Komun. Islam, vol. 5, no. 1, pp. 83-97, 2015.

DOI: 10.15642/jki.2015.5.1.83-97

[16] P. Celot and J. M. Pérez Tornero, "Study on Assessment Criteria for Media Literacy Levels: A comprehensive view of the concept of media literacy and an understanding of how media literacy levels in Europe should be assessed," Brussels, 2009. Google Scholar

[17] B. Trilling and F. Charles, 21St Century Skills learning for life in our times. San Fransisco: Jossey-Bass A Wiley Imprint, 2009.

ISBN ISBN: 978-1-118-15706-0

[18] T. Putri, N. Tenku, N. Abdul, N. Fariza, and M. Noor, "Digital Literacy Competence for Academic Needs: An Analysis of Malaysian Students in Three Universities," Procedia - Soc. Behav. Sci., vol. 69, pp. 1489-1496, 2012.

DOI: 10.1016/j.sbspro.2012.12.090

[19] R. M. Cordell, "Information literacy and digital literacy: Competing or complementary?," Commun. Inf. Lit., vol. 7, no. 2, pp. 177-183, 2013.

DOI: 10.15760/comminfolit.2013.7.2.150

[20] E. Nurjanah, A. Rusmana, and A. Yanto, "Hubungan Literasi Digital dengan Kualitas Penggunaan E-Resources," Lentera Pustaka J. Kaji. IImu Perpustakaan, Inf. dan Kearsipan, vol. 3, no. 2, pp. 117-140, 2017.

Google Scholar 